\title{
Model of the International Financial Grid and the Panama Papers
}

\author{
Frederick Betz \\ Portland State University, Portland, Oregon, USA \\ Email: fbetz@venture2reality.com
}

How to cite this paper: Betz, F. (2017) Model of the International Financial Grid and the Panama Papers. Theoretical Economics Letters, 7, 764-781.

https://doi.org/10.4236/tel.2017.74056

Received: July 12, 2016

Accepted: June 10, 2017

Published: June 13, 2017

Copyright $\odot 2017$ by author and Scientific Research Publishing Inc. This work is licensed under the Creative Commons Attribution International License (CC BY 4.0).

http://creativecommons.org/licenses/by/4.0/

\begin{abstract}
One of the advantages of empirically-grounded theory is to provide a deeper understanding of natural events. This is true both of the physical and social sciences, and especially of economic theory. We examine an empirical event in economics in 2016, called the "Panama Papers". Reports on the event provide material for an empirical case study about the international financial grid, focused upon the use of dummy corporations in "dark money" international-capital-flows. We analyze the case though a topological model of the international financial grid.
\end{abstract}

\section{Keywords}

Financial Grid, Financial Markets, International Capital Flows, Tax Evasion

\section{Introduction}

The validity of an economic model of the international financial grid depends methodologically upon the interaction of three research techniques: (1) economic theory formulated at a middle-range-theory level, (2) economic theory validated by cases of historical economic experience, and (3) topological models of economic systems providing an analytical framework to connect theory to reality. The economic interpretation of the importance of the event of the "Panama Papers" is facilitated by a topological model of the international financial grid [1].

\section{Historical Case: Panama Papers}

In the spring of 2016, a major news event was the release of business files from a Panama law firm, which revealed data about how dummy corporations were being used to hide finances located in the off-shore banking network. Michael S. Schmidt and Steven Lee Myers reported: "A group of news media outlets pub- 
lished articles on Sunday based on what they said were 11.5 million leaked documents from a Panama law firm that helped some of the world's wealthiest people-including politicians, athletes and business moguls-establish offshore bank accounts. The German newspaper Süddeutsche Zeitung said its reporters had obtained the documents from a confidential source. The newspaper then shared the files with other media organizations, like The Guardian and the International Consortium of Investigative Journalists. In an article, the investigative journalism organization said the documents revealed the offshore accounts of 140 politicians and public officials, including a dozen current and former world leaders and several individuals with close ties to President Vladimir V. Putin of Russia. The organization said reporters at 100 news media outlets working in 25 languages had used the documents to investigate the law firm, Mossack Fonseca, and its clients, including political figures in countries like Iceland, Pakistan and Saudi Arabia. It is not illegal in many cases to have offshore bank accounts. But they are used in some instances by wealthy individuals and criminals to hide money and business transactions, and to avoid paying taxes" [2].

\section{Background: Model of a Financial Grid}

As shown in Figure 1, we recall that what is particular to financial markets is a time-dimension; and this allows a financial market to deviate, over time, from price equilibrium to disequilibrium. In a financial market, financial products of capital assets are traded, and a capital asset has two economic values-current rent and future liquidity. Over time from $\mathrm{T}_{1}$ to $\mathrm{T}_{2}$, trading in the market can move from a price-equilibrium point to price disequilibrium, when a market gets hot and traders borrow money to purchase the asset at higher and higher prices [3].

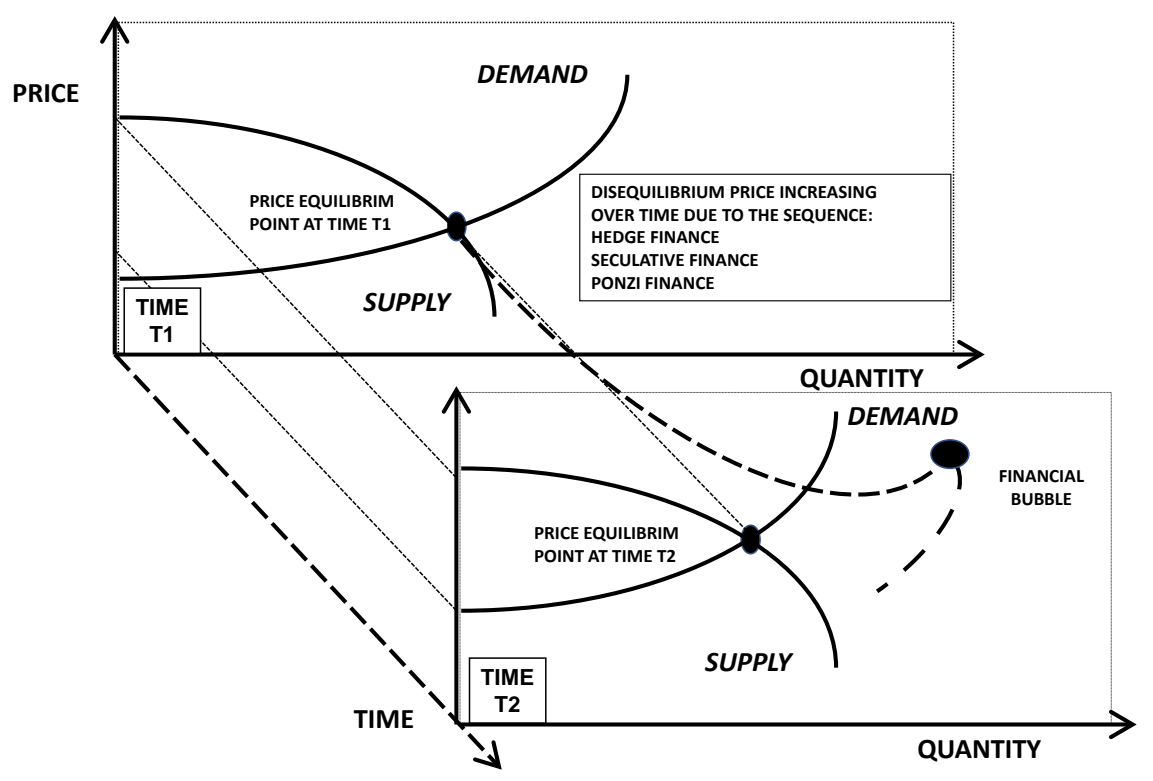

Figure 1. Keynes/minsky financial process. 
The debt can be in increasing percentage of asset price as the market gets "hot". This is possible by using greater leverage in the loans that traders obtain to trade in the market. Debt makes a financial process operate. Yet one aspect of debt can destabilize the process; and this is "leverage". To increase profit, traders use debt to finance the purchase of capital assets. Profits can be increased through financial leverage; and this is the financial rational of "leverage" (more "present-debt" toward greater "future-wealth"). However, as shown in Figure 2, when present-debt is too large (too highly leveraged), it might not create future-wealth but, instead, bankruptcy [3] [4].

One can use a disequilibrium model of a financial market as the central piece in modeling how the products of that market are produced and sold. This is the basic economic role of investment banking, to create and sell financial products of capital assets. As shown in Figure 3, the investment bank process can be depicted in systems notation, with a "disequilibrium financial market model" in the middle of the system - with a demand side and a supply side [1]. The financial market is composed of financial products created by investment banksproducts which match capital supply (demand side) to capital need (supply side). The investment bank creating financial products for a financial market is the center of the systems model. To the right side (supply side) of the systems model are sellers of capital assets, and to the left side are buyers of capital assets (demand side). Investment banks provide the banking intermediary creating the financial products which sell capital assets to buyers.

In systems notation, the "cloud" symbols are "sources" as origins of things entering the "flow" of the system-things which flow along the "arrow" lines of the system. The "rectangle" symbols are stocks of things which receive, send, or hold the things flowing along the arrows. The "circle-with-triangle" symbols are "control valves" which control the "rate-of-flow" of things along the arrows of

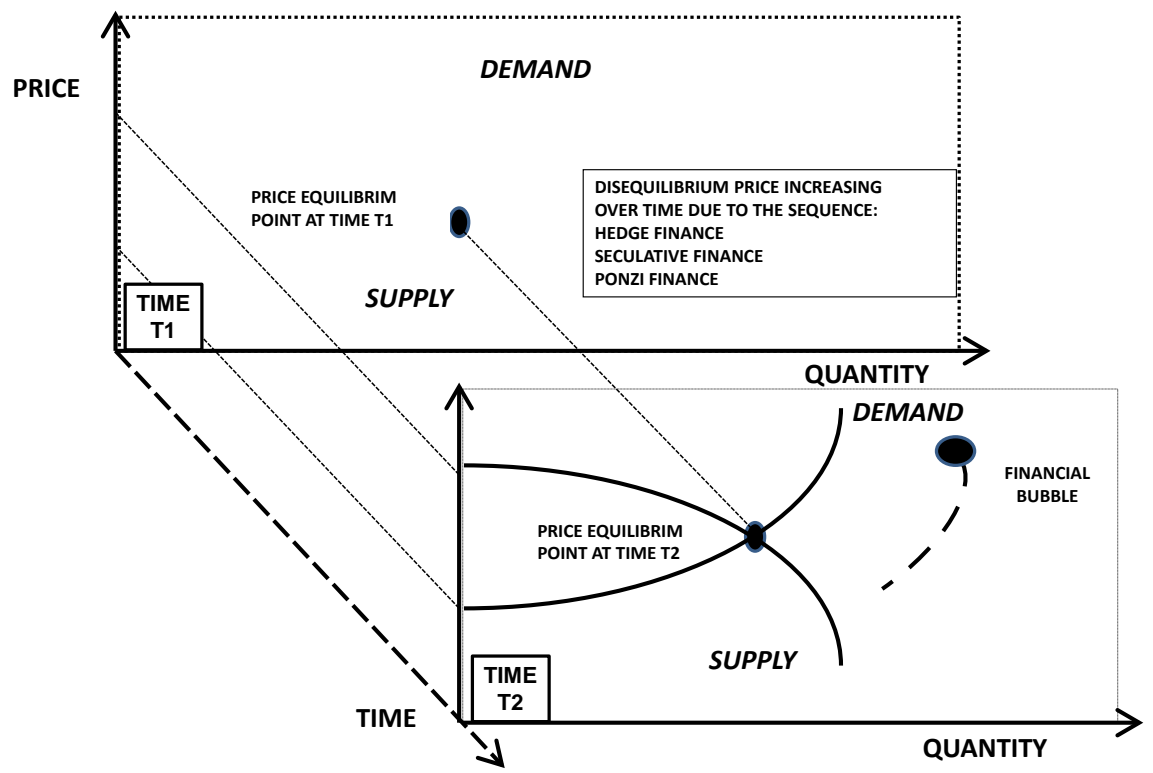

Figure 2. Disequilibrium pricing in a financial market over time. 


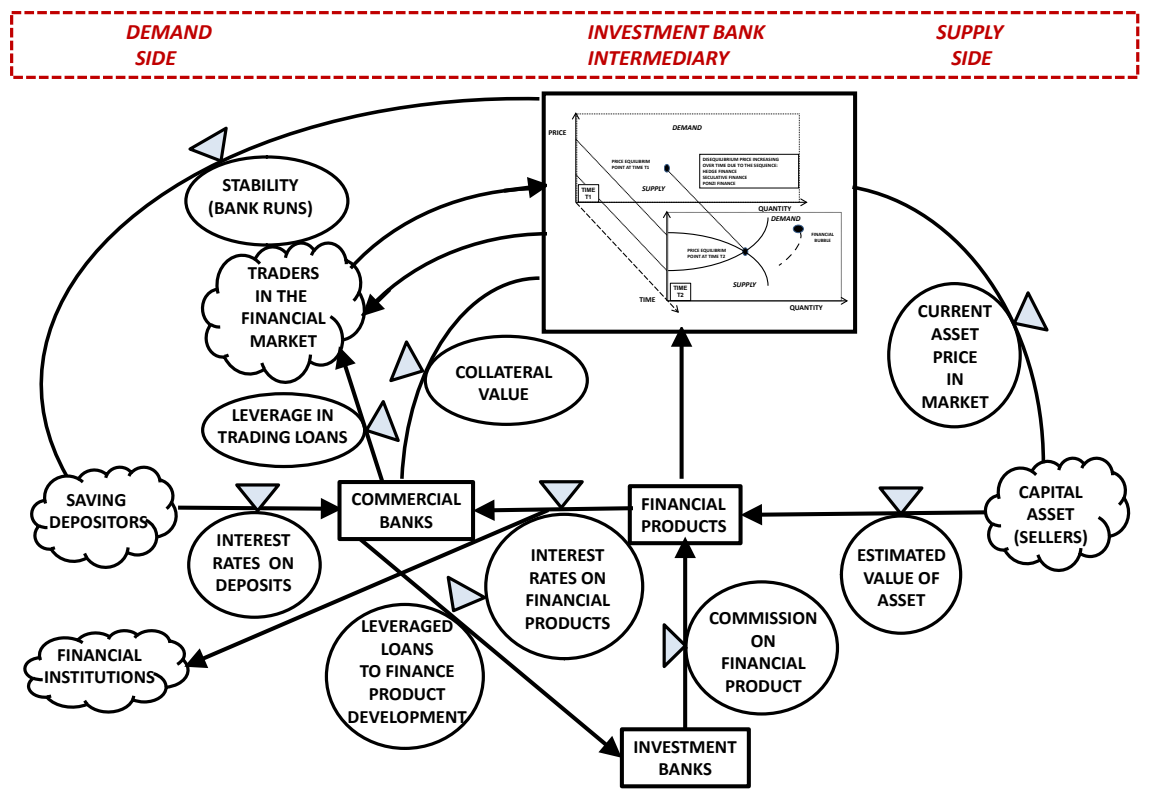

Figure 3. Disequilibrium systems model of investment bank process.

the system. The "system" model of an institutional process indicates a flow of things between sources and stocks in the system, controlled by valves along the flow lines. In this systems model of investment bank procedures, there are two sources: a source of savings (buyers) and a source of assets (sellers). The flow is "capital" from a source of savers to a source of asset sellers, through the intermediary of the creation and trading of "financial products"-products created by investment banks and traded in a financial market. The "price-disequilibrium" aspect of the investment process model is that in the financial market (which over time might go into a financial bubble due to trader speculation in the market), then a Minsky moment occurs when the financial bubble collapses.

To model the demand side of financial products, the source of savings are individuals who make deposits in commercial banks, and the commercial banks purchase financial products. Also other financial institutions (mutual funds, hedge funds, pension funds, insurance companies) purchase financial products. The interest rate on the financial product is the controlling rate for its purchase by commercial banks and financial institutions. Commercial banks also make leveraged loans to traders in the financial market; and the trader's purchase of financial products is then held as collateral by the banks. Commercial banks use interest from a financial product to pay interest to their savings depositors.

This models the abstraction of "Wall Street" in terms of a price-disequilibrium systems model of a financial market-created in the process of connecting the supply side (sellers) to the demand side (buyers), with investment banks acting as financial intermediaries. Suzanne Mcgee wrote: "All of the players (on Wall Street) perform functions that link the 'buy side', those who have capital and want to invest it profitably, and the 'sell side'," those entities in need of capital. "At its heart, when it is doing what it does best, Wall Street is a superb gatekeeper, making matches between investors and businesses, governments, or anyone 
else who needs to finance something," explains Mike Heffernan, a former Morgan Stanley banker" [5].

The stability of the commercial banks can then depend (1) upon the quantity of financial product purchased by the bank and (2) upon the value of the collateral held on loans to traders. If the financial market collapses, then commercial banks are saddled with valueless financial products and the bad loans of the traders. The banks can become insolvent. For example, in the New York stock market collapse of 1929, stocks held as collateral in banks (which made loans to traders purchasing stocks-on-margin) became valueless; and many of these banks went bust, through 1930, 1931, and 1932. Later in the 2007 derivatives market crash, some large U.S. banks (holding mortgage bonds as collateral) collapsed; and others holding such collateral would have collapsed, except for the U.S. government bail-out.

Thus the disequilibrium model of a financial market is composed of the financial products which trade capital assets; and the financial market may move toward price disequilibrium, if and when the market becomes hot, as traders bid the price of the financial product higher into a financial bubble. As traders bid higher prices in the market, they need increasing larger leverage in the loans for purchase. When the leverage in the loans gets too high, then the market grows into a financial bubble and can collapse. In a financial market collapse, the financial products which the commercial banks have held as collateral can become valueless (toxic assets). The banks can become insolvent and collapse (bank runs).

Next in modeling the international financial grid, one needs to add international banking grids as a separate plane to national financial grids. In particular, to understand the "buy-side" of the international financial grid, one must analyze the "off-shore banking industry". To add the model of this, one needs two topological planes: one to diagram the system of financial transactions in the grid and a second to diagram the institutional connections of off-shore banks to the centralized international investment banking system, Figure 4 .

These two planes are (1) the disequilibrium financial systems plane and (2) the institutions of the off-shore banking network which connect to an international financial center. The offshore banking network operates by: (a) collecting savings deposits from individuals \& corporations seeking financial secrecy, (b) setting up an institutional account with an investment bank in the City of London financial center, and (c) purchasing financial products from the investment banks in London.

Two topological planes are necessary because there are two different networks in the financial grid: (1) investment bank network and (2) off-shore banking network. These two networks are connected through the City of London Financial Center. This model shows that the offshore-bank network is financially effective because it ties into a central location, the City of London Financial Center. The City of London does not regulate the international investment banks dealings with the offshore network-as sellers (investment banks) and buyers 


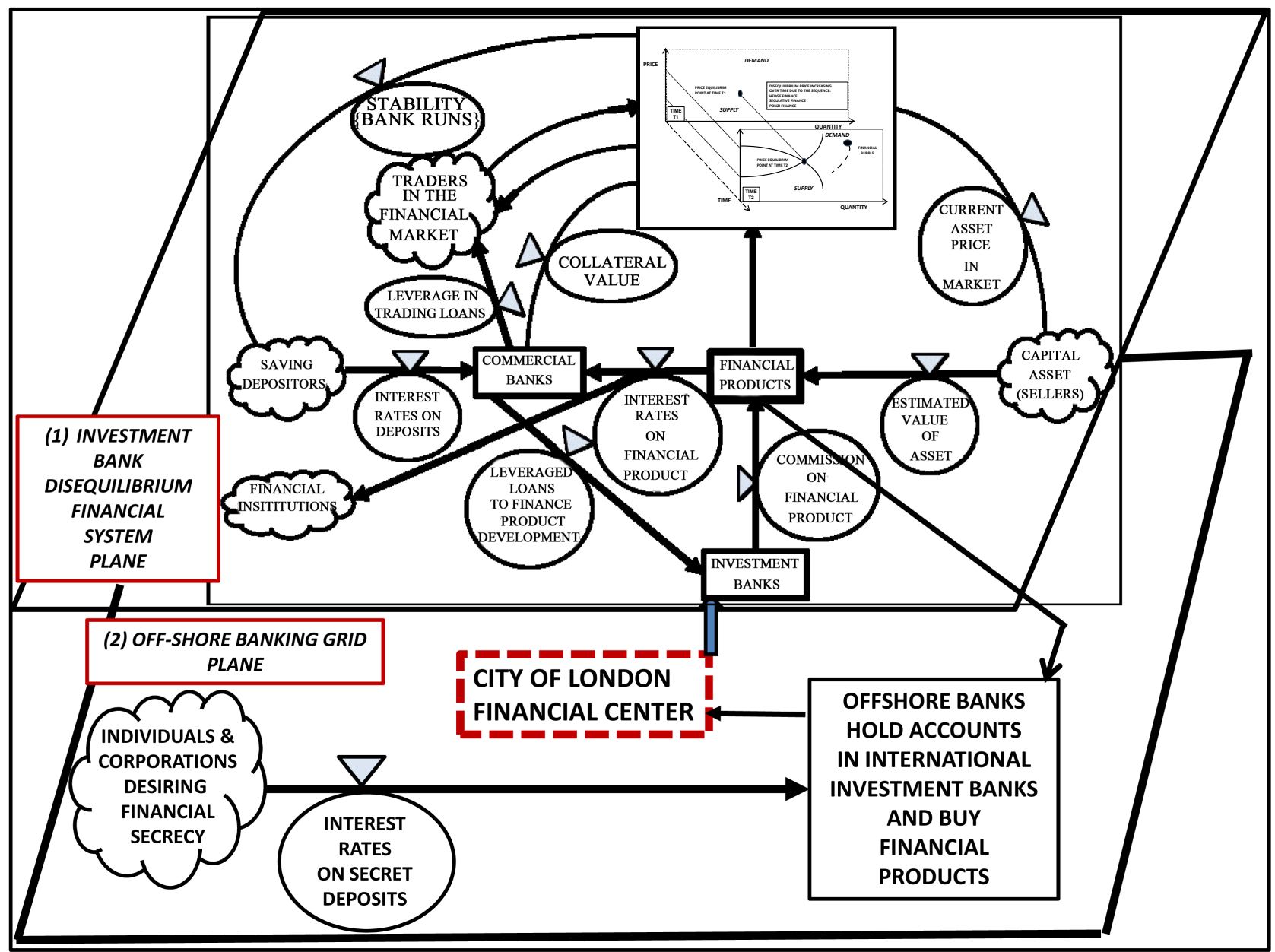

Figure 4. Modern international financial grid with off-shore banking.

(offshore banks) — of financial innovations which may (or may not) have public good. Transparency in a financial market tends to display characteristics of both private and public good in the market. In contrast, non-transparency (secrecy or obscurity) in a market tends to display characteristics only of private good with little or no public good (such as "black market" operations). The model emphasizes that some of the international buyers of the investment banks "financial innovations" were the off-shore banks which needed high-interest income to pay interest to their secret clients-individuals and corporations depositing in the off-shore banks. These off-shore banks do not care about the soundness of the financial products, just as long as the investment banks assure them that they are low-risk and bear high interest.

How does the City of London act as a center for the off-shore banking network? Nicholas Shaxson wrote: “The next component of the City's offshore status is its role in running, protecting, and being fed by Britain's offshore spider web. This web of partly British tax havens around the world provides the City with three things. First, it captures passing foreign business and assets nearby and channels them, and the business of handling them, to London, just as a spider web catches insects. Second, it is a storage mechanism for assets. Third, it 
is a kind of money-laundering filter that lets the City get involved in foreign dirty business but at sufficient distance to minimize the stink" [6].

In the 1950s, the Bank of England had allowed the Midland Bank to engage in foreign exchanges, and this began the deregulation of banks located in the City of London. Later in 1986, London financial deregulation was enacted formally by the Margaret Thatcher's government. The London Stock Market would no longer charge fixed trading commissions and investment banks could act for both buyers and sellers in the trading. The "Big Bang" in London deregulated fixed commissions on stock trades in Britain, forcing British investment banks to financially "innovate" (just like on the U.S. Wall Street). Nicholas Shaxson wrote: "By the early 1980s the main elements of the modern offshore system were in place and growing explosively. An older cluster of European havens, nurtured by old European aristocracies and led by Switzerland, was now being outpaced by a new network of more flexible, aggressive havens in the former outposts of the British Empire, themselves linked intimately to the City of London. A state within the British state, the City had been transformed from an old gentleman's club operating the financial machinery of empire, steeped in elaborate rituals and governed by unspoken rules about what 'isn't done', into a new, brasher, deregulated global financial center dominated by American banks and linked intimately to this new British spider web" [6].

To show the "grid" or network nature of the international financial system of cash flow, one next inserts a third plane between the national and international planes to explicitly indicate three banking networks involved in the grid, Figure 5.

A systems dynamics disequilibrium-pricing model of a financial grid provides the structural framework (macro-economic) for a functional analysis of actual institutional procedures (micro-economics). Of the three kinds of networks, the off-shore banking network is deliberately secret and unregulated; and the City of London investment banking network is largely unregulated. What the Panama Papers data provide is information about how this financial grid is used for secrecy in international capital flows.

\section{Historical Case: Panama Papers (Continued)}

The law firm whose files were disclosed in the Panama Papers caper, had been started by Jurgen Mossack and Ramon Fonseca. Kirk Semple, Azam Ahmed and Eric Lipton reported: "The two men (Mossack and Fonseca) came together in an era of political and economic uncertainty in Panama: one a reserved German immigrant whose father served in the armed wing of the Nazi party, the other a gregarious, aspiring novelist whose family opposed Panama's military dictatorship. With the nation still under the sway of Gen. Manuel Noriega, the pair merged their small law firms in 1986, creating what would become a powerhouse of secretive offshore banking for the elite. Over the next three decades, Jürgen Mossack and Ramón Fonseca expanded their practice to a staff of 500, with affiliate companies around the world and a client list of the powerful, the famous 


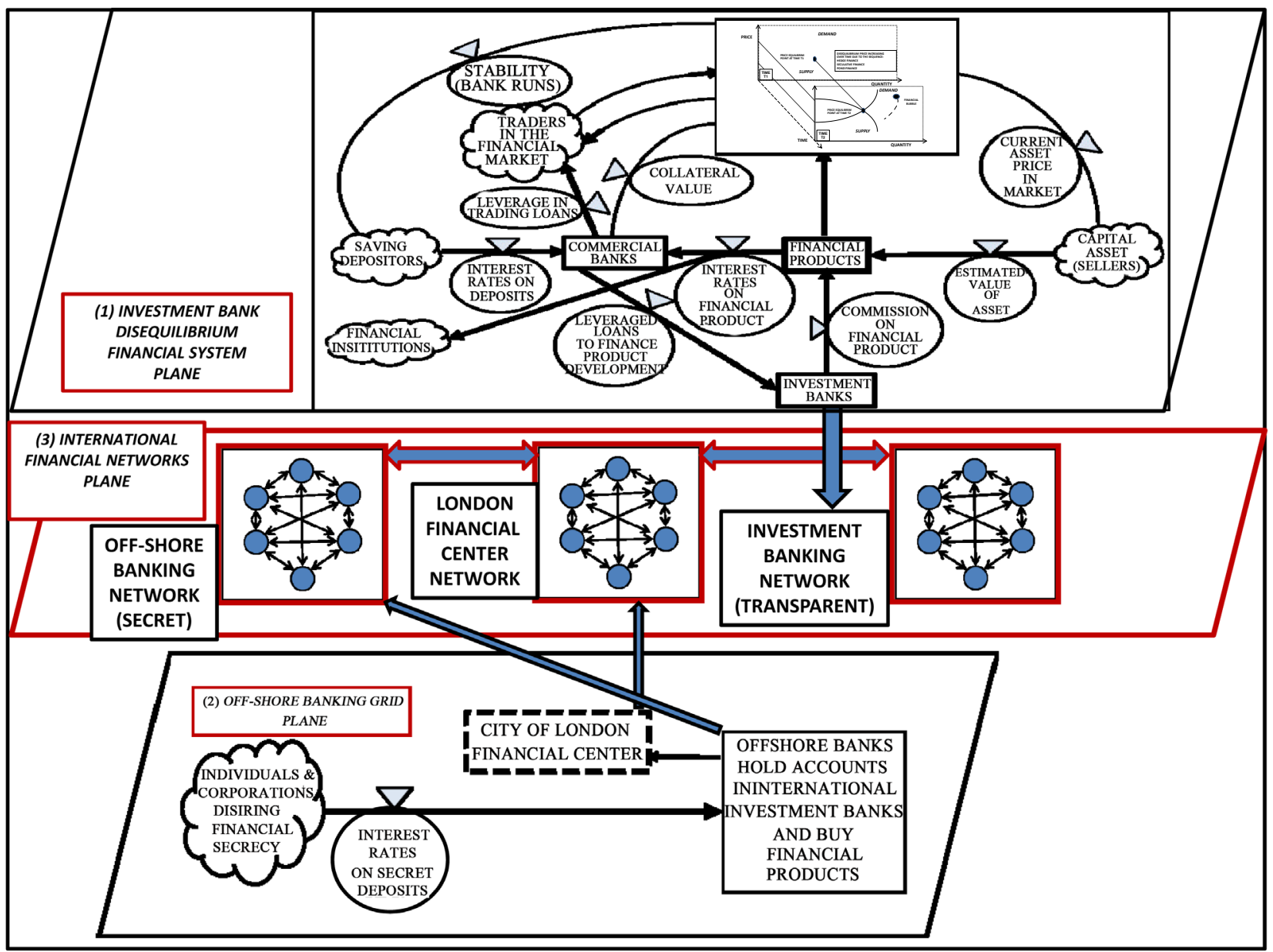

Figure 5. International financial grid as connected networks.

and, sometimes, the infamous. In January, a prosecutor investigating the sweeping corruption in Brazil publicly called their law firm "a huge money launderer" [7].

With the lack of financial regulation in Panama under the corrupt dictatorship of Noriega, the law firm of Mossack and Fonseca was able to expand their law service for secrecy and money-laundering in the international financial "black market". All markets can have secret operations, when unregulated. Black markets allow taxed items or unsafe items or illegal items to be sold under or outside of government regulation. (The outstanding example of this has been the international drug black market, wherein government law enforcement has been incapable of stopping or even decreasing international drug flows, over the past several decades.)

Kirk Semple, Azam Ahmed and Eric Lipton reported: “The partners had become very wealthy, and Mr. Fonseca leveraged the firm's success to gain an influential role in the upper ranks of politics. He told associates that he wanted to clean up the government, serving as a special adviser to President Juan Carlos Varela until the corruption scandal in Brazil forced Mr. Fonseca to resign this year. In an interview, he said that entering politics was, in part, a way of giving 
back. 'I believe in sharing the pizza,' he wrote. 'At least to give others one slice.' The firm, Mossack Fonseca, was built on assurances of bulletproof privacy for its clients. But its operations were laid bare this week by a vast leak of millions of documents that have helped expose the proliferation of shell companies and tax havens for the world's wealthiest people" [7]. The benefits of successful operations in a black market can be huge: providing wealth, prestige, and political power.

As an example of one use of secretive corporate services which the Panamanian law firm provided, Eric Lipton and Julie Creswell reported a case: "Over the years, William R. Ponsoldt had earned tens of millions of dollars building a string of successful companies. He had renovated apartment buildings in the New York City area. Bred Arabian horses. Run a yacht club in the Bahamas, a rock quarry in Michigan, an auto-parts company in Canada, even a multibillion-dollar hedge fund. Now, as he neared retirement, Mr. Ponsoldt, of Jensen Beach, Fla., had a special request for Mossack Fonseca, a Panama-based law firm well placed in the world of offshore finance: How could he confidentially shift his money into overseas bank accounts and use them to buy real estate and move funds to his children? " $\mathrm{He}$ is the manager of one of the richest hedge funds in the world," a lawyer at Mossack Fonseca wrote when the firm was introduced to Mr. Ponsoldt in 2004. "Primary objective is to maintain the utmost confidentiality and ideally to open bank accounts without disclosing his name as a private person." In summary, the firm explained: "He needs asset protection schemes, which we are trying to sell him." Thus began a relationship that would last at least through 2015 as Mossack Fonseca managed eight shell companies and a foundation on the family's behalf, moving at least $\$ 134$ million through seven banks in six countries-little of which could be traced directly to Mr. Ponsoldt or his children" [8].

Thus in the model of the international financial grid, this example illustrates that it is lack of proper regulation and enforcement that allows financial black markets to exist and be profitable, Figure 6.

\section{Dark Money in International Financial Flows}

Traditionally, the term of a "black market" for finances has been used for foreign currency exchanges in countries which tried to control an official exchange rate far above "market" levels. In the case of secrecy in the international capital flow, a term of "dark money" has been used. For example, Tom Burgis wrote: "Dark money: London's dirty secret. An insider at a Swiss bank warned Britain's financial watchdogs that bankers in its UK office were offering services that could facilitate tax evasion and money laundering. Did the regulators turn a blind eye?" [9].

Regulation and enforcement is the key to the viability of "dark" financial markets. The desire of individuals to avoid taxes or hide profits provides the customers for a secretive market for financial flows-dark money. Yet regulation of UK banks for dark money operations wasn't occurring. Tom Burgess wrote: 


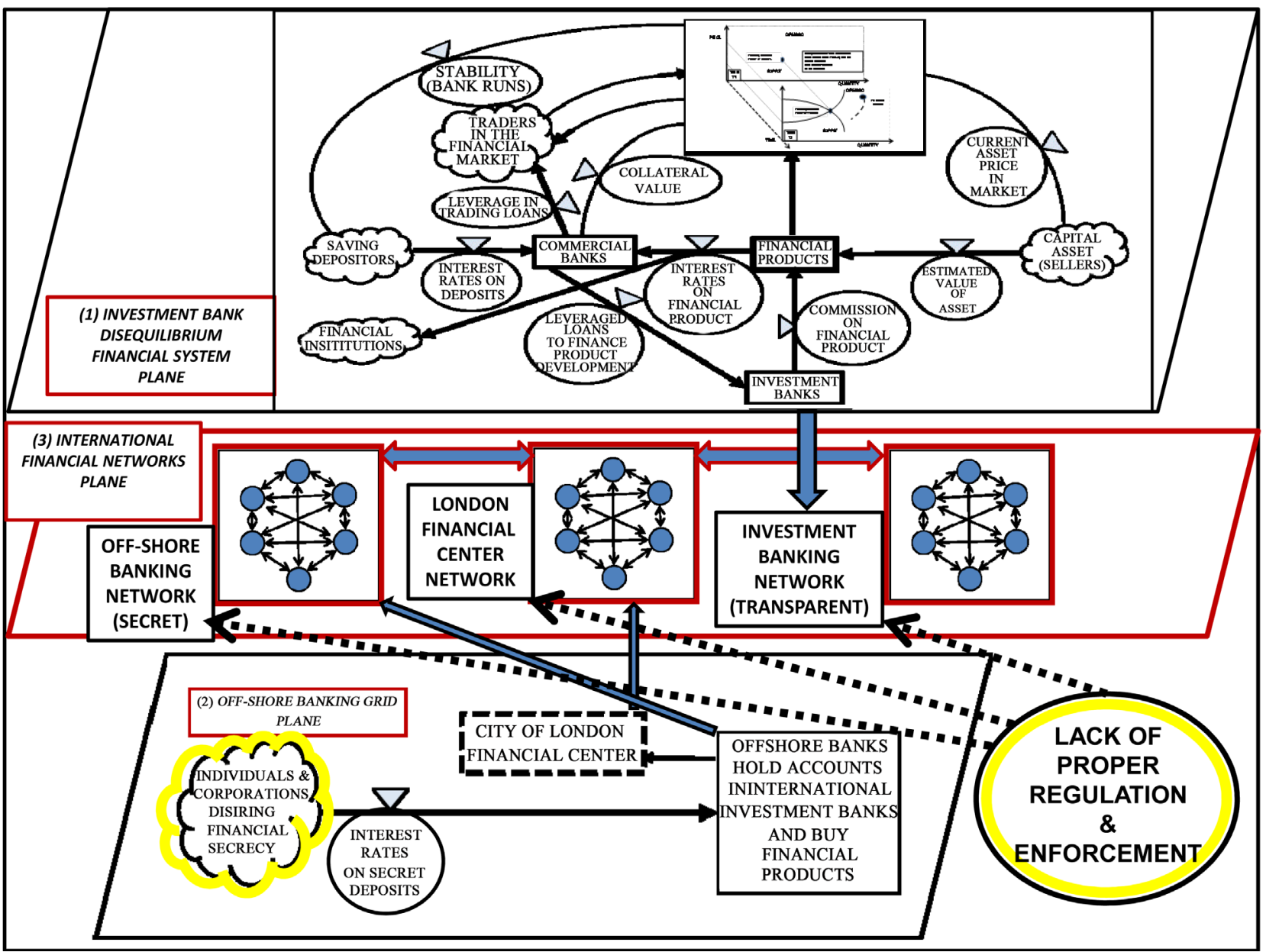

Figure 6. International financial grid as connected networks.

"One Monday in March last year, an announcement by the US justice department caught the attention of a former employee of the Swiss bank BSI. BSI's bosses had agreed to violate the first rule of Swiss banking. To escape prosecution for abetting tax evasion, the bank would disclose the names of its clients and reveal the tricks it had used to hide their wealth. The former BSI employee, who asks to be referred to only as Andrea, had worked in the bank's UK office on Cheapside in the heart of the City of London. In 2008, Andrea was among the industry insiders who were starting to worry about London's role as a global hub for illicit finance. That September, Andrea had warned the UK's financial watchdogs that BSI bankers were using secretive techniques that could allow clients to conceal assets, potentially facilitating tax evasion and money laundering. The regulators took no public action against the bank ...” [9].

The size and extent of the international financial dark market was also indicated by the Panama Papers disclosures. Eric Lipton and Julie Creswell reported: "In recent weeks, the papers' revelations about Mossack Fonseca's international clientele have shaken the financial world. The Times's examination of the files found that Mossack Fonseca also had at least 2400 United States-based clients over the past decade, and set up at least 2800 companies on their behalf in the 
British Virgin Islands, Panama, the Seychelles and other jurisdictions that specialize in helping hide wealth. Many of these transactions were legal; there are legitimate reasons to create offshore accounts, particularly when setting up a business overseas or buying real estate in a foreign country. But the documents-confidential emails, copies of passports, ledgers of bank transactions and even the various code names used to refer to clients-show that the firm did much more than simply create offshore shell companies and accounts. For many of its American clients, Mossack Fonseca offered a how-to guide of sorts on skirting or evading United States tax and financial disclosure laws. These included locating an individual from a "tax-convenient" jurisdiction to be the straw man owner of an offshore account, concealing the true American owner, or encouraging one client it knew was a United States resident to use his foreign passports to open accounts offshore, again to avoid scrutiny from regulators, the documents show. If the compliance department at one foreign bank contacted by Mossack Fonseca on behalf of its clients started to ask too many questions about who owned the account, the firm simply turned to other, less inquisitive banks" [8].

About the ineffectiveness for public good, of secrecy in the financial grid, the investigative reporter Nicholas Shaxon commented: "About 60 percent of world trade happens inside multinational corporations, which cut taxes by shuffling money between jurisdictions to create artificial paper trails that shift their profits into zero-tax havens and their costs into high-tax countries. The complexity and cost of this system cause great harm. But these maneuverings are invisible in corporations' annual reports. Under current accounting rules corporations can scoop up all their results-profits, borrowings, tax payments, and so on-from several countries and consolidate each into one figure, perhaps broken down by region. So a corporation may publish its profits from, say, Africa, but nobody can unpick those numbers to work out the profits in each country. You can't find the information anywhere. Trillions of dollars worth of cross-border flows simply disappear from view. So a citizen in a country where a multinational operates cannot tell from these reports even whether that corporation operates there, let alone what it does, its level of activity, its profits, its local employment, or its tax payments. As multinationals become ever more complex, this problem just gets worse" [6].

The range of services the law firm provided was intended to completely hide a financial transaction. Eric Lipton and Julie Creswell reported: "In 2006, using a secret email account set up by Mossack Fonseca so his correspondence would not be traced by the authorities, a businessman from Washington State asked a common question among the firm's potential American clients: "How does a US citizen legally get funds to Panama without the knowledge of the US government and how can those funds be profitably invested without the US government knowing about them?” The reply came from Ramsés Owens, then a partner who helped run the firm's trust division, offering clients "effective solutions to enhance your privacy, protect your wealth. Mr. Owens laid out a basic menu of 
services: a package deal setting up an offshore company in what he promised would be a relatively cheap and quick transaction. "We have right now a special offer by which we create a Private Foundation/company combination for a flat fee of US \$4,500.00,” Mr. Owens said. "It includes Charter Documents, Regulations, nominee officers and directors, bank account and management of funds, provision of authorized signatories, neutral phone and fax numbers and mail forwarding services for both the private foundation and its underlying company." With this legal structure in place, Mr. Owens went on to explain, any money placed in these accounts would essentially go into a black hole. "If we create a Private Foundation and the underlying company for you, the funds become completely private (US cannot know) as soon as the funds are deposited under a bank account or investment account in the name of the underlying company or the private foundation," he wrote. The benefits of such an arrangement were numerous, he added, detailing how the client could effectively evade United States tax laws while protecting himself-and the firm. "You can take the money in cash, you can do a bad investment; you can purchase something and not receive anything (an expensive piano, an expensive software)," Mr. Owens wrote. "You can receive an invoice from Panama or any other location and that would justify some of the outgoing moneys". You can also declare everything to the tax administration. "Any decision you make, please be aware that you will have to sign a 'disclaimer' to us. We can only 'suggest,' but the final decision to take the money out of the country is fully yours, and under the professional opinion of someone in USA" [8].

Liam Stack, Steven Erlanger, Bryant Rousseau, Michael Forsythe, Neil MacFarquhar and Stephen Castle wrote: "Who was named in the leaked documents? Among others, the documents named close associates of President Vladimir V. Putin of Russia, the father of Prime Minister David Cameron of Britain and relatives of President Xi Jinping of China and members of the Chinese Communist Party Politburo Standing Committee. Articles published by news organizations in cooperation with the International Consortium of Investigative Journalists also named King Salman of Saudi Arabia; Sigmundur David Gunnlaugsson, who resigned as prime minister of Iceland after the revelations; President Mauricio Macri of Argentina; and the soccer star Lionel Messi, one of the world's wealthiest athletes. Other soccer players; officials from FIFA, the sport's world governing body; and UEFA, the governing body of European soccer, were also tied to firms incorporated offshore through the Panamanian firm ... Those prominent names were among the hundreds of people that the papers tie to thousands of offshore shell companies. Such companies can be used to shield vast wealth from tax collectors, regulators and creditors. Many of the people named in the papers have denied in the strongest terms that they have broken any laws. Mr. Putin said allegations that his friends shuffled $\$ 2$ billion among several shell companies were an American plot to undermine Russian unity. Mr. Cameron, whose father was a client of the Panamanian law firm, initially said he had not benefited from any "offshore funds," only to confirm later that he and his wife 
had profited when they sold shares in an offshore trust for 30,000 pounds $(\$ 42,160)$ in 2010 , the year he became prime minister. The dividends they earned were declared and taxed, Mr. Cameron said" [10].

The New York Times Editorial Board wrote: "At its most basic, the U.S. law requires American citizens to disclose their foreign holdings and pay any taxes on capital gains, interest and dividends earned on those holdings. Noncompliance with the law is rampant: Unpaid taxes on foreign accounts are estimated at $\$ 40$ billion to $\$ 70$ billion a year. Emails and other correspondence between Mossack Fonseca and some of its American clients discuss efforts to conceal assets and evade taxes" [11].

\section{Adding to the International Financial Grid Model the Role of Law Firms}

From the data in the Panama Papers, one sees the important role that law firms play in facilitating the dark market in finance through offering services to set up and run shell corporations for clients desiring financial secrecy. Figure 7 adds to the financial grid model of law firm sources, in contributing to the formation of shell companies operating in the grid.

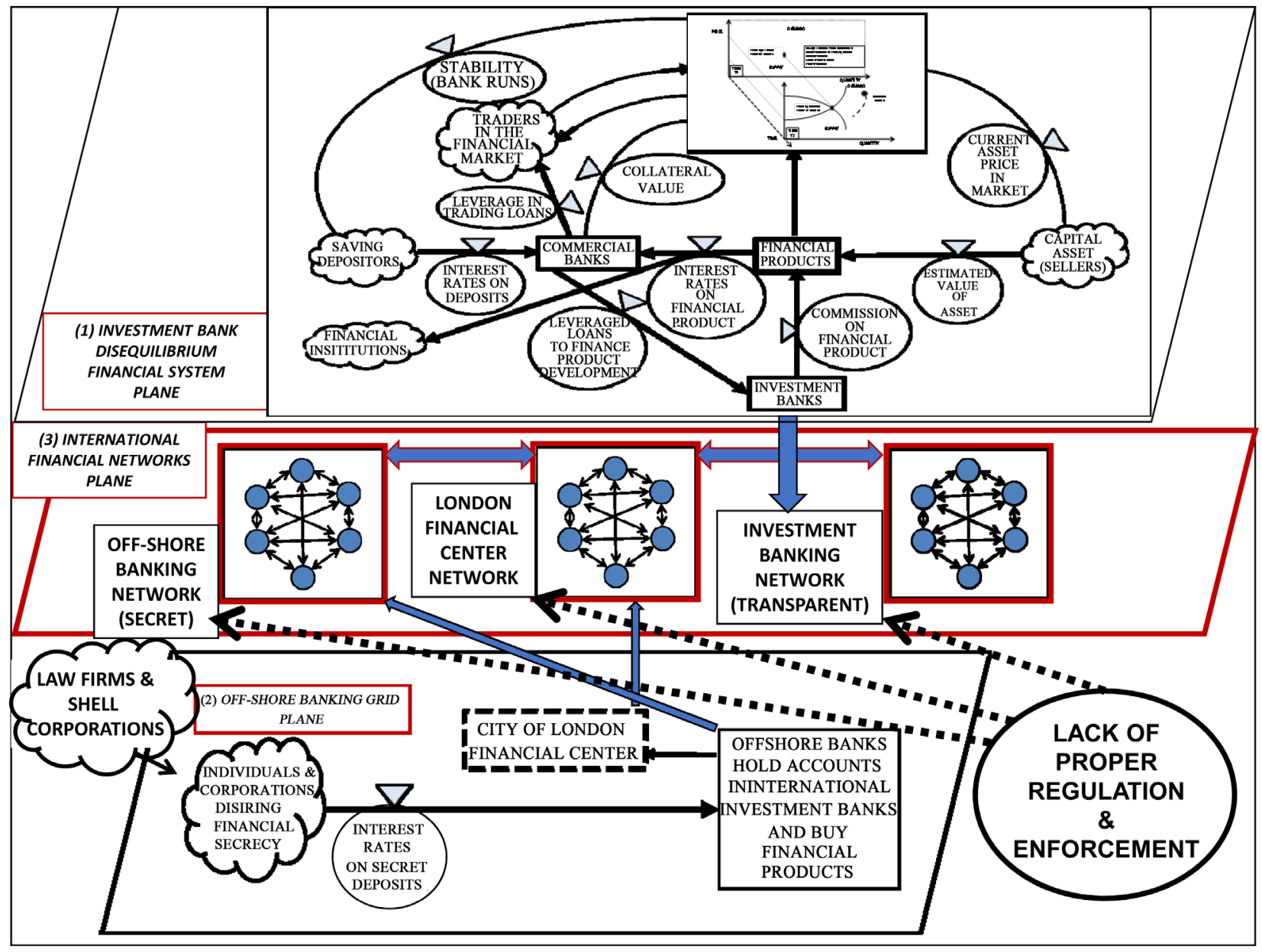

Figure 7. International financial grid as connected networks. 
What is useful about this research technique of developing graphic models of financial systems from empirical case studies is not only can the model (1) facilitate the interpretation of contemporary financial events but also (2) the model can be modified by new data to come closer to modeling economic reality.

\section{Historical Case: Panama Papers}

Eric Lipton and Julie Creswell wrote: "Over the years, tens of millions of dollars flowed into a series of shell companies-Escutcheon Investment, with its money at the Banca Privada in the Pyrenees principality of Andorra; Probity Investments, with deposits at Andbanc Grup Agricol, also in Andorra; Royal Pacific Investments, with deposits at Balboa Securities in Panama; and Valdano Investments Group, with deposits at Berenberg Bank in Switzerland, among others, the bank records and other documents show. Panama has long specialized in creating unusual foundations like Edenstone that are neither subject to Panamanian taxes nor required to support charitable causes. They do, however, allow the investors who "contribute" their financing to shield themselves from legal claims in the United States" [8].

When some of the individuals involved in the shell corporations set up through Panama became public, there were some repercussions. Steven Erlanger, Stephen Castle, and Rick Gladstone wrote: "The revelation of vast wealth hidden by politicians and powerful figures across the globe set off criminal investigations on at least two continents on Tuesday, forced leaders from Europe to Asia to beat back calls for their removal and claimed its first political casualty-pressuring the prime minister of Iceland to step down ... Prime Minister Sigmundur David Gunnlaugsson, confronted by demands for his resignation after documents revealing that he and his wealthy wife had set up a company in the British Virgin Islands led to accusations of a conflict of interest, asked his deputy to take over on Tuesday. In Britain, Prime Minister David Cameron faced calls for a government inquiry and accusations of bald hypocrisy by championing financial transparency-when the leaks showed that his family held undisclosed wealth in tax havens offshore. In Pakistan, where roughly 20 percent of the population live on less than $\$ 1.25$ a day, Prime Minister Nawaz Sharif angrily rebuffed opposition calls to resign, defended his riches as legally acquired, and demanded that his opponents back up their allegations of wrongdoing. His daughter said on Twitter to critics: prove or apologize. Officials in France, Germany, Austria and South Korea said they were beginning investigations into possible malfeasance, from money laundering to tax evasion. France's finance minister, Michel Sapin, told Parliament the government was putting Panama back on a blacklist of havens for tax evaders. In China, where the figures identified in the leaked papers include a brother-in-law of President Xi Jinping, the government denounced reports about them as a groundless attack. Its media censors purged mentions of Panama and blocked Internet search inquiries with that word. And in Russia, where officials also dismissed the leaked documents as a baseless political attack on Mr. Putin, the prosecutor general's office said 
Tuesday it would look into the reports that high-profile Russian individuals were beneficiaries of offshore companies" [12].

Some movement toward reform by governments occurred, but none sufficient to correct the international black-market in finance. The New York Times Editorial Board wrote: "In 2009, leaders of the Group of 20 nations, distressed by the global financial crisis, pledged to dismantle the tax havens that have allowed the world's richest people to avoid paying taxes. The United States and European governments were equally concerned about banks being used by tax cheats and criminals in a shadowy international financial system. In response, most nations have taken significant steps to make it harder and riskier to hide money overseas. The leaders of 132 nations have agreed to adopt an information-sharing standard developed by the Organization for Economic Cooperation and Development. Of those, 96 are expected to start sharing banking information over the next couple of years through an automated system designed to allow the tax authorities of participating governments to see the overseas holdings of their citizens. But one major international financial hub has refused to sign on-Panama. The recent leak of millions of documents from the Panamanian law firm Mossack Fonseca, which specializes in enabling shadowy overseas transactions, may change that. President Juan Carlos Varela of Panama announced Wednesday that his government will appoint a team of local and international experts to propose measures the country can take to "strengthen the transparency of the financial and legal systems'. Officials in Panama have pointed out that the American banking system has not been a model of transparency either. They are right. The United States remains one of the world's top tax havens. Several states have eagerly attracted foreign capital by making it easy to set up shell corporations and other legal entities that hide the identities of the owners. While the United States government has taken some steps to address this problem, they have been insufficient" [13].

Reuters reported: "The European Commission will propose on Tuesday stricter rules on trusts to prevent tax evasion, according to draft legislation seen by Reuters, in a move that Britain has long opposed and which was deferred until after the Brexit referendum. The EU push to identify owners of trusts has been in the making for years but British Prime Minister David Cameron had succeeded in blocking past attempts by EU authorities, citing a need for privacy for British trusts used to manage inheritances ... Over the past weeks, the British government lobbied the Commission again to avoid a crackdown on trusts. The EU executive postponed the decision until after the June 23 referendum on EU membership" [14].

Scott Shane wrote: "In recent days, Sri Lanka, Zimbabwe and South Africa joined the growing list of countries hunting down tax evaders among citizens who own offshore accounts. The French bank BNP Paribas said it would shut its Cayman Islands branch. In Pakistan, a cricketer turned politician who had attacked the prime minister over his family's offshore accounts admitted that he, too, had used a shell company. And the Group of 7 nations, meeting in Japan, agreed to crack down on illicit finance. It was the latest fallout from the Panama 
Papers [15].

\section{Conclusions}

In this case, we can see the importance of a research methodology which connects economic case studies with topological models of economic processes. This approach integrates historical case-study descriptions with model analysis for "middle-range" economic theory. In this case, the middle-range economic theory for which the panama papers disclosure provides empirical evidence is that financial markets can have a dark aspect, black-markets, when regulation is absent or unenforced.

The use of historical cases in establishing the institutional context of economic theory has a long tradition. For example, Robert C. Merton and Zvi Bodie commented upon "historical context": (We) propose a functional approach to design and manage the financial systems of countries, regions, firms, households, and other entities. This is a synthesis of the neoclassical, neo-institutional, and behavioral perspectives. Neoclassical theory (middle-range theory) is an ideal driver to link science and global practice in finance because its prescriptions are robust across time and geopolitical borders. By itself, however, neoclassical theory (middle-range-theory) provides little prescription or prediction of the institutional structure of financial systems-that is, the specific kinds of financial intermediaries, markets, and regulatory bodies will or should evolve in response to underlying changes in technology, politics, demographics, and cultural norms. The neoclassical model (middle-range-theory) therefore offers important, but incomplete guidance to decision makers ... [16].

What Merton and Bodie meant by the phrase "neoclassical theory" is that social science theory (in their case, economic theory) needs to be constructed as valid in any society at any time-but not without context. They called neoclassical theory as "important but incomplete"-incomplete until societal context is added. This is because the "functional processes" of the institutional structures in specific societies may deviate from "ideal processes" (neoclassical theory)due to behavior or "inefficiencies" of that society at that time. Behavioral patterns can create departures for the predictions (projections) of the neoclassical middle-range generalizations. All social theory (including economic theory) can be generalized to social structure/function representation (structural functionalism), which is context-dependent upon specific institutional contexts. Middle-range societal theory provides an "ideal" theory of how structure-functions can operate in any society-but is modified by an institutional context of the society. Systems models of institutional flows of capital enable the comparison of different historical cases-in order to generalize and depict middle-range economic theory as models.

Ideal social theory (such as perfect markets) is incomplete until context is added. Empirically-real economic theory is always context-dependent. This is why economic historiography in the form of "historical case studies" is empirically necessary to economics (and to all social sciences) - to provide the context- 
dependency of theory.

Without empirically-real economic models, economic policy can be ineffective. For example in 2000, the then Chair of the U.S. Federal Reserve System argued to the U.S. Congress that the derivatives market should not be regulated because all markets were perfect; and then the mortgage derivatives market subsequently collapsed the U.S. economy in 2008 [17].

In this paper, we have depicted how the validity of a model of the international financial grid depends methodologically upon the integration of three research techniques: (1) economic theory formulated at a middle-range level, (2) economic theory validated by cases of historical economic experience, and (3) topological models of economic events providing the analytical framework to connect theory to reality. The Panama Papers event adds empirical information about the secrecy in models of the international financial grid.

\section{References}

[1] Betz, F. (2015) Price-Disequilibrium Model of the International Financial Grid: Innovation, Crisis, and Off-Shore Banking. Business and Management Research, 4. www.sciedupress.com/bmr

[2] Schmidt, M.S. and Steven, L.M. (2016) Panama Law Firm's Leaked Files Detail Offshore Accounts Tied to World Leaders. New York Times, April 3.

http://www.nytimes.com/2016/04/04/us/politics/leaked-documents-offshore-accou nts-putin.html

[3] Betz, F. (2014) Disequilibrium Pricing Theory. Theoretical Economics Letters, 4, Article ID: 1500464. http://www.scirp.org/journal/tel

[4] Minsky, H.P. (1982) Can "It" Happen Again? Essays on Instability and Finance, M.E. Sharpe Inc., Armonk, New York.

[5] Mcgee, S. (2010) Chasing Goldman Sachs: How the Masters of the Universe Melted Wall Street Down ... and Why They'll Take Us to the Brink Again. Crown Publishing Group, USA.

[6] Shaxson, N. (2011) Treasure Islands: Uncovering the Damage of Offshore Banking and Tax Havens. St. Martin's Press. Palgrave McMillan.

[7] Semple, K., Ahmed, A. and Lipton, E. (2016) Panama Papers Leak Casts Light on a Law Firm Founded On Secrecy. New York Times, April 6.

http://www.nytimes.com/2016/04/07/world/americas/panama-papers-leak-casts-lig ht-on-a-law-firm-founded-on-secrecy.html

[8] Lipton, E. and Julie, C. (2016) Panama Papers Show How Rich United States Clients Hid Millions Abroad. New York Times, June 5.

http://www.nytimes.com/2016/06/06/us/panama-papers.html?_r=0

[9] Burgis, T. (2016) Dark Money: London's Dirty Secret. Financial Times, May 11. http://www.ft.com/cms/s/2/1d805534-1185-11e6-839f-2922947098f0.html

[10] Liam, S., Erlanger, S., Rousseau, B., Forsythe, M., MacFarquhar, N. and Castle, S. (2016) The Panama Papers: Here's What We Know. New York Times, April 4. http://www.nytimes.com/2016/04/05/world/panama-papers-explainer.html

[11] Editorial Board (2016) Panama Papers Point to Tax Evasion. New York Times, June 6. http://www.nytimes.com/2016/06/07/opinion/panama-papers-point-to-tax-evasion. $\underline{\mathrm{html}}$ 
[12] Erlanger, S., Castle, S. and Gladstone, R. (2016) Iceland's Prime Minister Steps down amid Panama Papers Scandal. New York Times, April 5.

http://www.nytimes.com/2016/04/06/world/europe/panama-papers-iceland.html

[13] Editorial Board (2016) Financial Secrecy in Panama and Beyond. New York Times, April 8.

http://www.nytimes.com/2016/04/08/opinion/financial-secrecy-in-panama-and-bey ond.html

[14] Reuters (2016) After Brexit, EU Proposes Tougher Tax Rules on Trusts. New York Times, July 4.

http://www.nytimes.com/reuters/2016/07/04/business/04reuters-britain-eu-tax-trus ts.html?_r=0

[15] Shane, S. (2016) Panama Papers May Inspire More Big Leaks, if Not Reform. New York Times, May 29.

http://www.nytimes.com/2016/05/30/us/politics/panama-papers-may-inspire-more -big-leaks-if-not-reform.html

[16] Merton, R.C. and Zvi, B. (2005) The Design of Financial Systems: Towards a Synthesis of Function and Structure. Journal of Investment Management, 3, 1-23.

[17] Betz, F. (2012) Control in Knowledge Economies. Journal of Knowledge Economy, 5, 761-783.

Submit or recommend next manuscript to SCIRP and we will provide best service for you:

Accepting pre-submission inquiries through Email, Facebook, LinkedIn, Twitter, etc. A wide selection of journals (inclusive of 9 subjects, more than 200 journals)

Providing 24-hour high-quality service

User-friendly online submission system

Fair and swift peer-review system

Efficient typesetting and proofreading procedure

Display of the result of downloads and visits, as well as the number of cited articles

Maximum dissemination of your research work

Submit your manuscript at: http://papersubmission.scirp.org/

Or contact tel@scirp.org 